\title{
ISOLATED INTESTINAL TUBERCULOSIS ASSOCIATED WITH HUMAN IMMUNODEFICIENCY VIRUS INFECTION
}

\author{
Petru E. MUNTEAN 1 四 \\ ${ }^{1}$ Emergency Hospital of Arges County, Pitesti, Romania
}

\author{
Received 13 Jan 2020, Accepted 15 Febr 2020 \\ hitps://doi.org/10.31688/ABMU.2020.55.1.22
}

\begin{abstract}
Introduction. Tuberculosis is a common and treatable human immunodeficiency virus-related (HIV) disease. Intestinal tuberculosis is much more recurrent in immunocompromised patients and presents as a complication of pulmonary tuberculosis due to swallow of infected sputum, hematogenic dissemination or even ingestion of contaminated milk. There is a strong need for close collaboration between HIV programmes and tuberculosis programmes.
\end{abstract}

Case presentation. A 48-year-old male patient presented for a three month history of frequent bowel movements (3-4 stools per day, without blood or mucus), a weight loss of eight kilograms, infrequent dry cough, fatigue, esophageal candidiasis, anorexia, persistent low-grade fever and intermittent pain in the right lower abdominal quadrant. Abdominal $\mathrm{X}$-Ray revealed a marked dilatation of the small intestine. High resolution axial computed tomography described thickening of the terminal ileum and medial caecal wall, with slightly enlarged low density nodes. Histopathological examination of the intestinal mucosa revealed granulomatous design and caseous necrosis. The positive diagnosis was primary extrapulmonary multidrug-resistant tuberculosis with HIV infection. He received an individualized and second line antituberculous treatment combined with

\section{Résumé}

Tuberculose intestinale isolée associée au syndrome d'immunodéficience

Introduction. La tuberculose est une maladie liée au virus de l'immunodéficience humaine courante et traitable. La tuberculose intestinale est beaucoup plus récurrente chez les patients immunodéprimés et se présente comme une complication de la tuberculose pulmonaire due à la déglutition des expectorations infectées, à la dissémination hématogène ou même à l'ingestion de lait contaminé. Il existe un fort besoin de collaboration étroite entre les programmes du virus de l'immunodéficience humaine et les programmes de lutte contre la tuberculose.

Présentation de cas. Patient de 48 ans, qui avait des antécédents de selles fréquentes pour une période de trois mois ( 3 à 4 selles par jour, sans sang ni mucus), une perte de poids de 8 kilogrammes, une toux sèche peu fréquente, de la fatigue, une candidose œsophagienne, une anorexie, fièvre persistante à bas degrè et douleur intermittente dans le quadrant abdominal inférieur droit. La radiographie abdominale a révélé une dilatation marquée de l'intestin grêle. La tomodensitométrie axiale à haute résolution a révélé un épaississement de l'iléon terminal et de la paroi caecale médiale; nœuds de faible densité légèrement agrandis. 
antiretroviral therapy. Later on, he developed pneumonia with Pneumocystis jirovecii. The patient had a good clinical response to all therapies.

Conclusions. Physicians should be aware that intestinal tuberculosis must be considered in the differential diagnosis of patients with abdominal symptoms, especially in immunocompromised patients.

Keywords: human immunodeficiency virus, extrapulmonary tuberculosis, sign of Fleischner, pneumonia with Pneumocystis jirovecii.

\section{INTRODUCTION}

Tuberculosis is a common and treatable human immunodeficiency virus (HIV)-related disease. A large group of patients with human immunodeficiency virus and pulmonary tuberculosis die from pulmonary complications despite receiving antituberculosis treatment (Table 1). There is a strong need for a close collaboration between HIV programmes and tuberculosis programmes.

New data suggest that starting antiretroviral therapy while still on tuberculosis treatment could improve outcomes, according to Camelia study ${ }^{1}$. At the same time, immune reconstitution inflammatory syndrome, which is frequently cited by specialists as a reason to delay starting antiretroviral therapy, was more common among people with early HIV treatment, but did not offset the survival benefit provided by earlier antiretroviral therapy.

Hardly seen in modern countries, intestinal tuberculosis affects mainly immunocompromised patients and immigrants ${ }^{2.5}$. The incidence of intestinal tuberculosis has been constantly increasing in the past twenty years but only a few cases with intestinal tuberculosis, with isolated colonic involvement, are reported $^{6-9}$.

Most important, intestinal tuberculosis should enter into the differential diagnosis (Table 2), especially in the lack of an active pulmonary infection, because it may mimic other abdominal diseases, such as: tumors, other infectious and inflammatory processes like abscess, and even Crohn's disease ${ }^{8}$.

Intestinal tuberculosis is much more recurrent in immunocompromised patients ${ }^{10}$ and presents as a
L'examen histopathologique de la muqueuse intestinale a révélé un dessin granulomateux et une nécrose caséeuse. Le diagnostic positif était une tuberculose extrapulmonaire multirésistante primaire avec infection par le VIH. Il a reçu un traitement antituberculeux individualisé et de deuxième ligne combiné à un traitement antirétroviral. Plus tard, il a développé une pneumonie à Pneumocystis Jirovecii. Malgré les problèmes cliniques existants, le patient a eu une bonne réponse clinique à toutes les thérapies.

Conclusions. Il est très important pour les médecins de savoir que la tuberculose intestinale peut être considérée comme un diagnostic différentiel chez les patients aux symptomes intestinaux, surtout les patients immunocompromis.

Mots-clés: virus de l'immunodéficience humaine, tuberculose extrapulmonaire, signe de Fleischner, pneumonie à pneumocystis jirovecii.

complication of pulmonary tuberculosis, due to swallow of infected sputum, hematogenic dissemination or even ingestion of contaminated milk ${ }^{11}$.

\section{Case presentation}

A 48-year-old male patient, presented for three months history of infrequent bowel movements (three-four stools per day, without blood or mucus), a weight loss of eight kilograms, infrequent dry cough, fatigue, esophageal candidiasis, anorexia, persistent low grade fever and intermittent pain in the right lower abdominal quadrant.

He was a widower, working in a street market. The patient had no history of tuberculosis. In childhood, he was vaccinated with Bacille Calmette-Guérin and there was no family history of any cancer. His medical history revealed intravenous drug use for the last three years, associated with alcohol drinking and cigarette smoking.

Physical examination showed slight abdominal tenderness, painful at palpation, mostly limited to the right lower quadrant. Laboratory tests revealed anemia with a decreased white blood cell count and increased $\mathrm{C}$ reactive protein levels. Chest X-Ray was normal. Stool samples were negative for infectious microorganisms. Urinalysis had normal values. Abdominal X-Ray revealed a marked dilatation of the small intestine (Figure 1).

High resolution axial computed tomography described thickening of the terminal ileum and medial caecal wall with slightly enlarged low density nodes (Figure 2). 


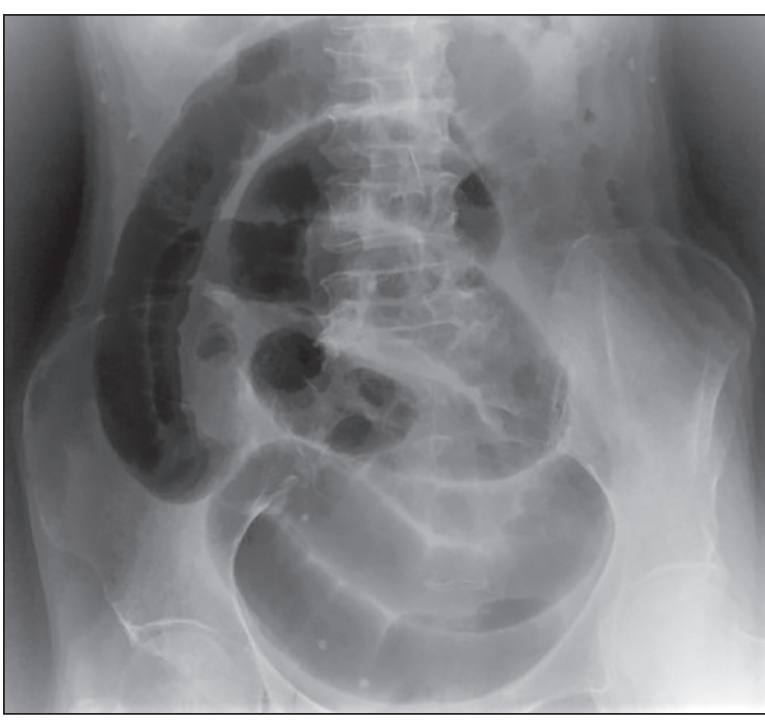

Figure 1. Abdominal radiography revealed a marked dilatation of the small intestine

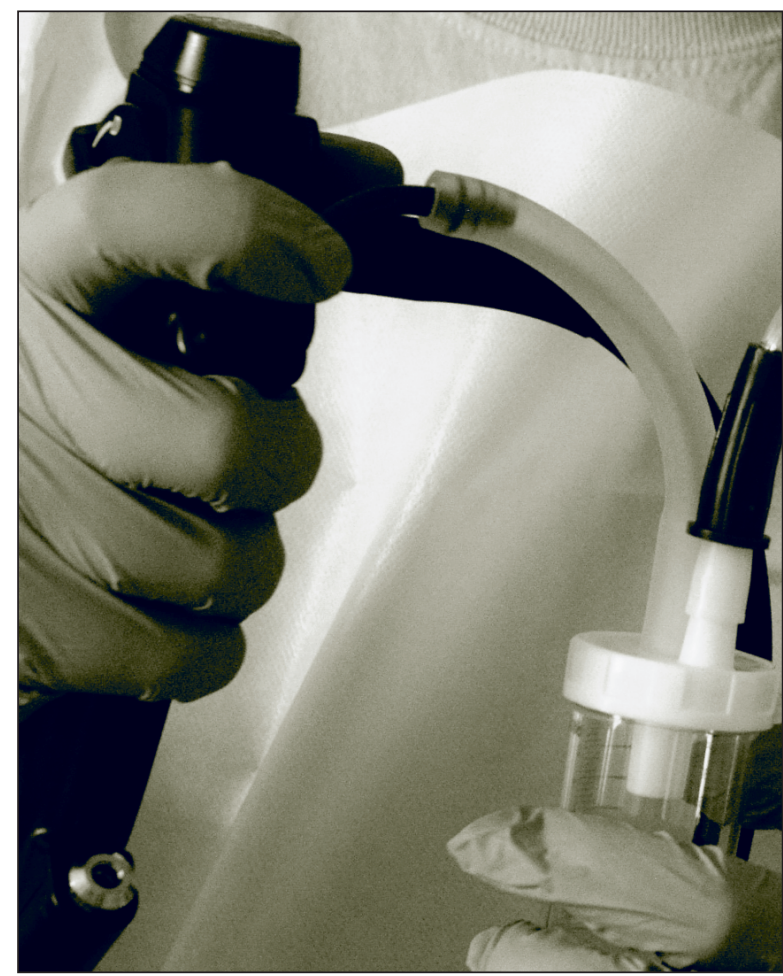

Figure 3. Bronchoalveolar lavage.

Barium follow through test was conducted and revealed the inverted umbrella sign of Fleischner. QuantiFeron-TB Gold negative. An apparently normal chest X-Ray is frequent in patients with intestinal tuberculosis, but does not exclude it. Both bronchoalveolar lavage (Figure 3) and gastric aspirate did not reveal acidfast bacilli.

The male patient was then referred to the Gastroenterology department, where colonoscopy was made. Biopsies from the tumoral lesion (Figure

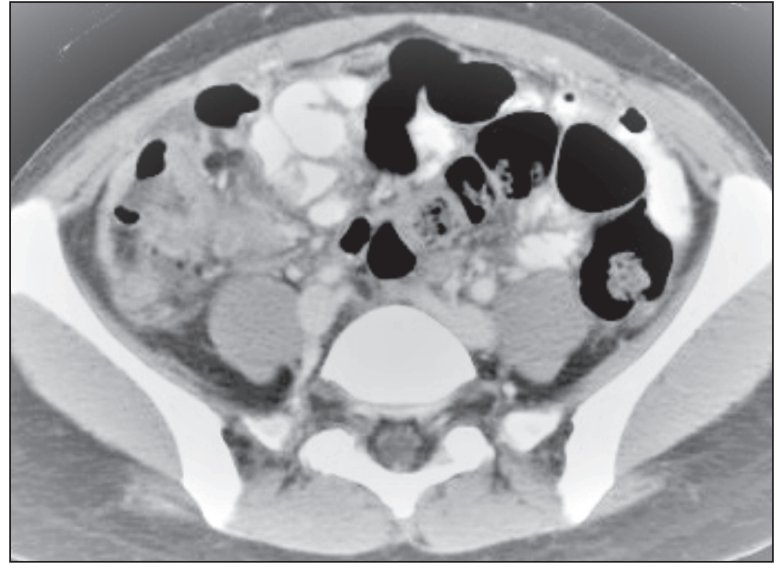

Figure 2. High resolution axial computed tomography revealed thickening of the terminal ileum and medial caecal wall with slightly enlarged low density nodes.

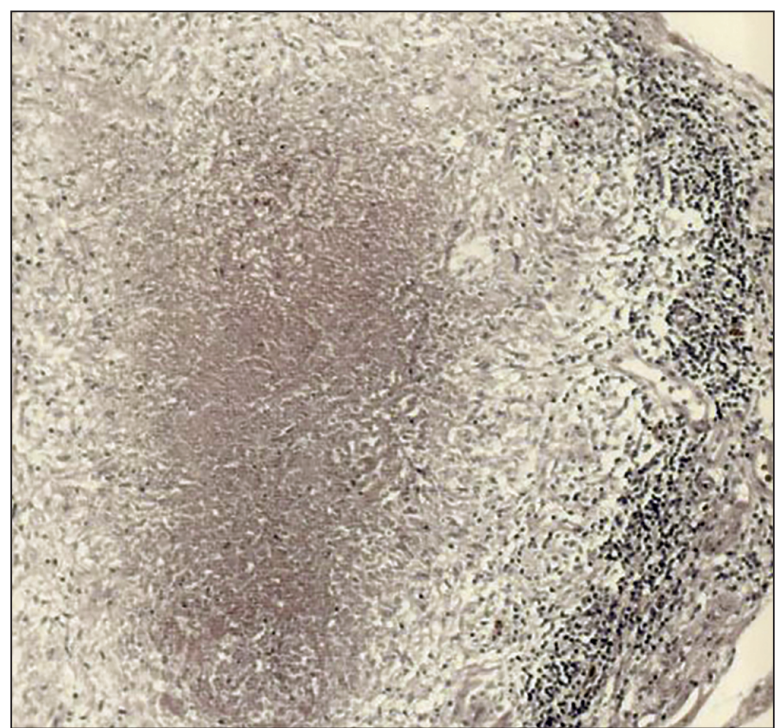

Figure 4. Histopathological examination of the intestinal mucosa: optical microscope with oil immersion objective (1000 X magnification), carbol fuchsin as primary stain, described granulomatous design and caseous necrosis

4) were evaluated and several tubercle bacilli were identified upon Ziehl Neelsen staining.

The detected Mycobacterium tuberculosis was resistant to isoniazid and rifampicin. Cultures were all negative. Because of the history of drug consumption and the clinical signs, an HIV test was performed, with a positive result. The positive diagnosis was extrapulmonary multidrug-resistant tuberculosis with HIV infection, sustained by histopathological examination of the intestinal mucosa and GeneXpert MTB/RIF. Because HIV test was positive, the patient was referred to a specialized infectious diseases center, where a cluster of differentiation four count of 
Table 1. Pulmonary manifestations of HIV-infected patients depending on cluster of differentiation four count.

\begin{tabular}{|c|c|c|c|c|}
\hline $\begin{array}{c}\text { Any cluster } \\
\text { of differentiation } 4 \text { count: }\end{array}$ & $\leq 500$ Cells $/ \mu \mathrm{L}$ & $\leq 200$ Cells $/ \mu L$ & $\leq 100$ Cells $/ \mu L$ & $\leq 50$ Cells $/ \mu L$ \\
\hline $\begin{array}{l}\text { 1. Upper respiratory tract } \\
\text { infection } \\
\text { 2. Sinusitis } \\
\text { 3. Pharyngitis } \\
\text { 4. Acute bronchitis } \\
\text { 5. Obstructive airway } \\
\text { disease } \\
\text { 6. Bacterial pneumonia } \\
\text { 7. Tuberculosis } \\
\text { 8. Non Hodgkin lym- } \\
\text { phoma } \\
\text { 9. Pulmonary embolus } \\
\text { 10. Bronchogenic carcinoma }\end{array}$ & $\begin{array}{l}\text { 1. Bacterial pneu- } \\
\text { monia } \\
\text { 2. Pulmonary } \\
\text { mycobacterial } \\
\text { pneumonia }\end{array}$ & $\begin{array}{l}\text { 1. Pneumocystis pneu- } \\
\text { monia } \\
\text { 2. Cryptococcus neo- } \\
\text { formans pneumonia } \\
\text { 3. Bacterial pneumonia } \\
\text { 4. Extrapulmonary } \\
\text { tuberculosis }\end{array}$ & $\begin{array}{l}\text { 1. Pulmonary } \\
\text { Kaposi sarcoma } \\
\text { 2. Bacterial pneu- } \\
\text { monia } \\
\text { 3. Toxoplasma } \\
\text { pneumonitis }\end{array}$ & $\begin{array}{l}\text { 1. Disseminated } \\
\text { Histoplasma capsu- } \\
\text { latum } \\
\text { 2. Disseminated } \\
\text { Coccidioides immitis } \\
\text { 3. Cytomegalovirus } \\
\text { pneumonitis } \\
\text { 4. Disseminated } \\
\text { Mycobacterium avium } \\
\text { complex } \\
\text { 5. Aspergillus infection }\end{array}$ \\
\hline
\end{tabular}

Table 2. Differential diagnosis between tuberculosis and Crohn's disease (medical imaging)

\begin{tabular}{ccc}
\hline & Tuberculosis & Crohn's disease \\
\hline Chest radiography & Positive chest film (in 50\% of cases) & Negative chest film \\
\hline Barium appearance & Fleischner sign & Cobblestone mucosa \\
\hline \multirow{2}{*}{$\begin{array}{c}\text { Computed tomography } \\
\text { appearance }\end{array}$} & No creeping fat & Creeping fat \\
\cline { 2 - 3 } & Omental and peritoneal thickening & Normal omentum and peritoneum \\
\cline { 2 - 3 } & Enlarged low density nodes & Enlarged soft tissue density nodes \\
\hline
\end{tabular}

two-hundred cells per cubic millimeter was revealed, in urgent need of specialized treatment.

After prolonged attempts to persuade the patient and professional psychotherapy, he agreed to an individualized and second line antituberculous treatment combined with antiretroviral therapy. The effective dose using weight-based protocol consists in the use of: Pyrazinamide + Amikacin + Levofloxacin + Clofazimine + Linezolid + Rifabutin (300 milligrams twice-weekly $)+$ Pyridoxine $(50 \text { milligrams daily })^{11}$.

During the first month, because the patient was reluctant and began treatment later than normal, he developed pneumonia with Pneumocystis jirovecii (Figure 5), treated with trimethoprim-sulfamethoxazole and corticosteroids as adjunctive therapy.

We had to consider the existing clinical issues: toxicities and drug interactions, ability to adhere to two complex treatment schemes and laboratory abnormalities. Using this regimen, the patient did not experience clinically significant increases in rifabutin serum levels and had a good clinical response to therapy ${ }^{11}$.

The recommended duration of treatment scheme for multidrug resistant tuberculosis in HIV-seropositive patients is twenty-four months and posttreatment follow-up visits to monitor for tuberculosis relapse should be conducted every four months, for a total of twenty-four months ${ }^{11}$.

\section{Discussion}

Intestinal tuberculosis may be considered as a differential diagnosis in immunocompromised patients who present vague abdominal symptoms and relevant physical findings, especially in cases with centered pain and palpable mass in the right lower

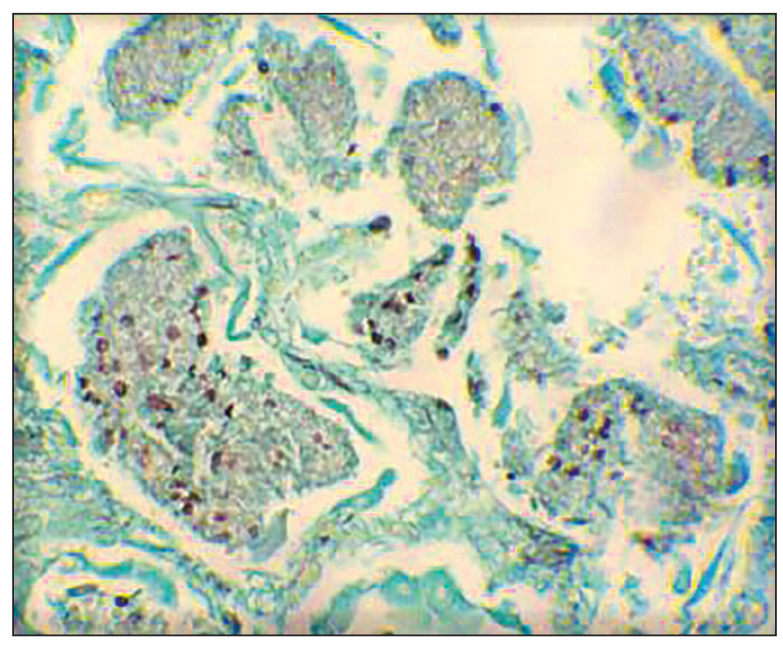

Figure 5. Histopathological examination from lung biopsy: optical microscope, low power oil immersion objective (100 X magnification), Gomori methenamine silver stain, showed that the walls of the cysts are stained black and appear as folded spheres. 
quadrant of the abdomen, in areas where tuberculosis is endemic (subregions of Eastern Europe).

Mycobacterium tuberculosis in HIV-positive patients is extremely difficult to treat. Adherence to treatment plays a significant role in the recovery and patients need constant professional psychological support. New treatments can prevent both symptoms and complications to evolve.

Together with lifestyle transformation and antiretroviral medications, most people with HIV infection can enjoy a lifetime similar to that of the general population. The integration of HIV and tuberculosis centers could serve as an important part in reducing and better managing the infected persons.

\section{Conclusions}

The gastrointestinal tract is the sixth site of extrapulmonary tuberculosis ${ }^{12}$. Ileocecal site is the most frequently infected part of the gastrointestinal tract in around $85 \%$ of cases ${ }^{12}$. The gastric inclusion is sporadic, possibly due to the acidity and insufficiency of lymphoid tissue and the rapid crossing of its content to the small bowel ${ }^{13}$.

Abdominal pain is the most constant symptom, present in $90 \%$ of situations, but other symptoms may occur: diarrhea, vomit, fever, nausea, loss of weight, abdominal distension, poor absorption, weakness and even constipation ${ }^{14,15}$. Low digestive hemorrhage is $\operatorname{rare}^{16}$. The preferred diagnostic procedure is colonoscopy with biopsy.

Clinical, radiological and endoscopic images of intestinal tuberculosis are most likely to be mistaken as neoplasms. Surgery is used only in case of diagnostic contrariety and also the decisive treatment to prevent issues of disease progression, such as stenosis or fistulas ${ }^{17}$.

Regarding the histological diagnosis, the frequent findings in tuberculosis are the large granulomas with central caseation, which are confluent and multiple ${ }^{18}$, although the most reliable finding in biopsies is the evidence of Mycobacterium tuberculosis ${ }^{19}$. Different forms of cancer may have an endoscopic appearance of circumferential thickening, with fistulas formation and ulcers that mimick Crohn's disease ${ }^{20}$.

Worldwide, there was an estimation of nine million incident cases of tuberculosis in 2013, 13\% co-infected with HIV ${ }^{21}$. There were an estimated one and a half million tuberculosis deaths (one million among HIV-negative people and half a million among HIV-positive people $)^{21}$.

It is important that physicians should be aware of the necessity of testing the gastric aspirate ${ }^{22}$, Lowenstein-Jensen culture of biopsy tissue taken during endoscopy, in the case Ziehl Neelsen doesn't demonstrate acid fast bacilli ${ }^{23}$. Enteroclysis followed by a barium enema may still be the best protocol for evaluation of intestinal tuberculosis ${ }^{24}$.

\section{Author contributions}

P. E. M. is responsible for the diagnostic procedures, clinical diagnosis, treatment decisions and also wrote the manuscript. The author has read and agreed to the published version of the manuscript.

\section{Compliance with Ethics Requirements:}

„The author declare no conflict of interest regarding this article"

"The author declare that all the procedures and experiments of this study respect the ethical standards in the Helsinki Declaration of 1975, as revised in 2008(5), as well as the national law. Informed consent was obtained from the patient included in the study"

Acknowledgments: none

\section{RefEREnCES}

1. Blanc FX, T. Sok, D. Laureillard, et al. Early (2 weeks) vs. late ( 8 weeks) initiation of highly active antiretroviral treatment (HAART) significantly enhance survival of severely immunosuppressed HIV-infected adults with newly diagnosed tuberculosis: results of the CAMELIA clinical trial. BMC Proceedings 2011 Vol. 5 (Suppl. 1): O11.

2. Singh V, Kumar P, Kamal J, Prakash V, Vaiphei K, Singh K. Clinico-colonoscopic profile of colonic tuberculosis. Am J Gastroenterol. 1996;91:565-568.

3. Probert CSJ, Jayanti V, Wicks AC, Carr-Locke DL, Mayberry JF. Epidemiological study of abdominal tuberculosis among Indian migrants and the indigenous population of Leicester, 1972-1989. Gut. 1992;33:1085-1088.

4. Chen WS, Leu SY, Hsu H, Lin JK, Lin TC. Trend of large bowel tuberculosis and the relation with pulmonary tuberculosis. Dis Colon Rectum. 1992;35:189-192.

5. Guth A, Kim U. The reappearance of abdominal tuberculosis. Surg Gynecol Obstet. 1991;172:432-436.

6. Palmer KB, Patil DH, Basran GS, Riordan JF, Silk DB. Abdominal tuberculosis in urban Britain. A common disease. Gut. 1985;26:1296-1305.

7. Watson JM, Gill ON. HIV infection and tuberculosis. Br Med J. 1990;300: 63-65.

8. Marshall JB. Tuberculosis of the gastrointestinal tract and peritoneum. Am J Gastroenterol. 1993;88:989-999.

9. Snider Jr DE, Roper WL. The new tuberculosis. N Eng J Med. 1992;326:703-705.

10. Pettengell KE, Larsen C, Garb M, Mayet FG, Simjee AE, Pirie D. Gastrointestinal tuberculosis in patients with pulmonary tuberculosis. Q J Med. 1990;74(275): 303-8.

11. Ministry of Health from Romania. Methodological Guide for Implementation of the National Programme for Prevention, Supervision and Control of Tuberculosis. Ed. ALPHA MDN. ISBN 978-973-139-325-4, Bucharest 2015.

12. Rubio T, Gaztelu MT, Calvo A, et al. Abdominal tuberculosis. An Sist Sanit Navar. 2005;28(2): 257-60. 
13. Mendes WB, Batista CAM, Lima HA, et al. Tuberculose intestinal como causa de obstrução intestinal: relato de caso e revisão de literatura. Rev Bras Coloproct. 2009;29(4): 489-92.

14. Rao YG, Pande GK, Sahni P, Chattopadhyay TK. Gastroduodenal tuberculosis management guidelines, based on a large experience and a review of the literature. Can J Surg. 2004:47(5): 364-8

15. Lazarus AA, Thilagar B. Abdominal tuberculosis. Dis Mon. 2007;53(1): 32-8.

16. Uzunkoy A, Harma M. Diagnosis of abdominal tuberculosis: experience from 11 cases and review of the literature. World J Gastroenterol. 2004;10(24): 3647-9.

17. Kuntanapreeda K. Tuberculous appendicitis presenting with lower gastrointestinal hemorrhage-a case report and review of the literature. J Med Assoc Thai. 2008;91(6): 937-42.

18. Bromberg SH, Faroud S, de Castro FF, Morrone N, de Godoy AC, Franca LC. Isolated ileocecal tuberculosis simulating malignant neoplasia and Crohn's disease. Rev Assoc Med Bras. 2001;47(2): 125-8.
19. Makharia GK, Srivastava S, Das P, et al. Clinical endoscopic, and histological differentiations between Crohn's disease and intestinal tuberculosis. Am J Gastroenterol. 2010;105:642-651.

20. DiLauro S, Crum-Cianflone N. Ileitis: when it is not Crohn's disease. Curr Gastroenterol Rep. 2010;12:249-258.

21. World Health Organization, author. Global Tuberculosis Report 2014. Geneva, Switzerland: World Health Organization; 2014.

22. Mishra PK, Bhargava A, Punde RP, et al. Diagnosis of gastrointestinal tuberculosis: Using cytomorphological, microbiological, immunological and molecular techniques - A study from Central India. Indian J Clin Biochem. 2010;25:158-163.

23. Maynard-Smith L, Larke N, Peters JA, Lawn SD. Diagnostic accuracy of the Xpert MTB/RIF assay for extrapulmonary and pulmonary tuberculosis when testing non-respiratory samples: a systematic review. BMC Infect Dis. 2014;14:709.

24. Vanhoenacker FM, De Backer AI, Op de BB, et al. Imaging of gastrointestinal and abdominal tuberculosis. Eur Radiol. 2004;14 (Suppl 3):E103-E115. 